\title{
Lifelong CRF overproduction is associated with altered gene expression and sensitivity of discrete $\mathrm{GABA}_{\mathrm{A}}$ and $\mathrm{mGlu}$ receptor subtypes
}

\author{
Christiaan H. Vinkers $\cdot$ Hendrikus Hendriksen $\cdot$ Ruud van Oorschot • \\ James M. Cook • Sundari Rallipalli • Shengming Huang • Mark J. Millan • \\ Berend Olivier • Lucianne Groenink
}

Received: 17 April 2011 / Accepted: 15 July 2011 /Published online: 11 August 2011

(C) The Author(s) 2011. This article is published with open access at Springerlink.com

\begin{abstract}
Rationale Repeated activation of corticotropin-releasing factor (CRF) receptors is associated with increased anxiety and enhanced stress responsivity, which may be mediated via limbic GABAergic and glutamatergic transmission. Objective The present study investigated molecular and functional alterations in $\mathrm{GABA}_{\mathrm{A}}$ receptor $\left(\mathrm{GABA}_{\mathrm{A}} \mathrm{R}\right)$ and metabotropic glutamate receptor (mGluR) responsivity in transgenic mice that chronically overexpress CRF.

Methods $\mathrm{CRF}_{1}$ receptor, $\mathrm{GABA}_{\mathrm{A}} \mathrm{R}$, and mGluR sensitivity were determined in CRF-overexpressing mice using the stress-induced hyperthermia ( $\mathrm{SIH})$ test. In addition, we measured mRNA expression levels of $\mathrm{GABA}_{\mathrm{A}} \mathrm{R} \alpha$ subunits and mGluRs in the amygdala and hypothalamus.
\end{abstract}

C. H. Vinkers $\cdot$ H. Hendriksen $\cdot$ R. van Oorschot $\cdot$ B. Olivier $\cdot$

L. Groenink

Division of Pharmacology, Utrecht Institute for Pharmaceutical

Sciences and Rudolf Magnus Institute of Neuroscience,

Utrecht University,

Universiteitsweg 99,

3584CG, Utrecht, The Netherlands

C. H. Vinkers $(\triangle)$

Department of Psychiatry, Rudolf Magnus Institute of

Neuroscience, University Medical Center Utrecht,

Utrecht, The Netherlands

e-mail: c.h.vinkers@uu.nl

J. M. Cook $\cdot$ S. Rallipalli $\cdot$ S. Huang

Department of Chemistry, University of Wisconsin-Milwaukee,

Milwaukee, WI, USA

\section{J. Millan}

Institute de Reserche Servier,

Croissy sur Seine, France

B. Olivier

Department of Psychiatry, Yale University School of Medicine, New Haven, CT, USA
Results CRF-overexpressing mice were less sensitive to the anxiolytic effects of the $\mathrm{CRF}_{1}$ receptor antagonists $\mathrm{CP} 154,526$ and DMP695, the $\mathrm{GABA}_{\mathrm{A}} \mathrm{R} \alpha_{3}$-selective agonist TP003 $(0-3 \mathrm{mg} / \mathrm{kg})$ and the $\mathrm{mGluR}_{2 / 3}$ agonist LY379268 $(0-10 \mathrm{mg} / \mathrm{kg})$ in the SIH test. The hypothermic effect of the non-selective $\mathrm{GABA}_{\mathrm{A}} \mathrm{R}$ agonist diazepam $(0$ $4 \mathrm{mg} / \mathrm{kg}$ ) and the $\alpha_{1}$-subunit-selective $\mathrm{GABA}_{\mathrm{A}} \mathrm{R}$ agonist zolpidem $(0-10 \mathrm{mg} / \mathrm{kg})$ was reduced in CRFoverexpressing mice. No genotype differences were found using the $\mathrm{GABA}_{\mathrm{A}} \mathrm{R} \alpha_{5}$-subunit preferential compound SH053-2' $\mathrm{F}-\mathrm{R}-\mathrm{CH}_{3}$ and mGluR $_{5}$ antagonists MPEP and MTEP. CRF-overexpressing mice showed decreased expression levels of $\mathrm{GABA}_{\mathrm{A}} \mathrm{R} \alpha_{2}$ subunit and $\mathrm{mGluR}_{3}$ mRNA levels in the amygdala, whereas these expression levels were increased in the hypothalamus. CRF-overexpressing mice also showed increased hypothalamic mRNA levels of $\alpha_{1}$ and $\alpha_{5} \mathrm{GABA}_{\mathrm{A}} \mathrm{R}$ subunits.

Conclusions We found that lifelong CRF overproduction is associated with altered gene expression and reduced functional sensitivity of discrete $\mathrm{GABA}_{\mathrm{A}}$ and mGluR receptor subtypes. These findings suggest that sustained over-activation of cerebral CRF receptors may contribute to the development of altered stress-related behavior via modulation of GABAergic and glutamatergic transmission.

Keywords SIH - Corticotropin-releasing factor - Anxiety . Stress · Temperature $\cdot$ Emotional fever Glutamate .

Benzodiazepine $\cdot$ Mouse

\section{Introduction}

The neuropeptide corticotropin-releasing factor (CRF) was initially characterized as the principal HPA-axis modulator in response to stress (Vale et al. 1981). However, CRF has 
been found to orchestrate autonomic, immune, and behavioral stress-related responses via central $\mathrm{CRF}_{1}$ and $\mathrm{CRF}_{2}$ receptors (Heinrichs and Koob 2004). These non-endocrine CRF brain circuits extend outside the hypothalamus and include cortical, limbic, striatal, and brainstem areas (Hauger et al. 2006). In line with a pivotal role in modulating the stress system, CRF dysfunction appears to be present in various psychiatric disorders including anxiety disorders, drug addiction, major depressive disorder, and schizophrenia (Binder and Nemeroff 2010; Hauger et al. 2009; Kehne and Cain 2010; Logrip et al. 2011; Millan 2003; Reul and Holsboer 2002).

A transgenic mouse model of long-term CRF overexpression has been proposed to model CRF dysfunction. In these animals, chronically elevated CRF levels in the central nervous system are associated with behavioral, neurochemical, autonomic, and physiological changes, including altered HPA axis activity, dexamethasone nonsuppression, and reduced heart rate variability (Groenink et al. 2003). These data suggest that chronic postnatal CRF overproduction in these mice leads to alterations mimicking findings that are associated with anxiety disorders and major depression (Binder and Nemeroff 2010; Licht et al. 2009; Linthorst 2005). Clearly, exogenous CRF administration has been found to elicit arousal and anxiety, putatively through $\mathrm{CRF}_{1}$ receptor stimulation (Bijlsma et al. 2011; Heinrichs et al. 1997; Kehne and Cain 2010; Millan 2003). However, other neurotransmitter systems such as the $\mathrm{GABA}_{\mathrm{A}}$ and glutamate system may adjust in response to (sub)chronic CRF receptor activation. In support, CRF has been shown to increase GABA release in the amygdala (Bagosi et al. 2008; Kash and Winder 2006; Nie et al. 2004) and striatum (Sirinathsinghji and Heavens 1989), while also affecting excitatory glutamatergic transmission depending on localization (pre/postsynaptic) and the CRF receptor type (Liu et al. 2004). Moreover, repeated central infusion of the CRF receptor agonist urocortin into the basolateral amygdala (BLA) resulted in long-lasting deficits in fast $\mathrm{GABA}_{\mathrm{A}}$ receptor-mediated inhibitory transmission which could be prevented by NMDA receptor antagonists (Rainnie et al. 2004). Therefore, the present study aimed to investigate the putative link between chronic central CRF overexpression and subsequent alterations in $\mathrm{GABA}_{\mathrm{A}}$ and glutamate receptor sensitivity. To this end, we used the stress-induced hyperthermia (SIH) test. This test is based on the fact that stress-induced increases in body temperature can be reversed by putative anxiolytics, including (non-)selective $\mathrm{GABA}_{\mathrm{A}}$ receptor agonists, metabotropic glutamate receptor (ant)agonists, and $\mathrm{CRF}_{1}$ receptor antagonists (Bouwknecht et al. 2007; Vinkers et al. 2008). If chronic CRF release elicits long-lasting changes in fast neurotransmitter systems, this would provide a putative mechanism by which
CRF dysfunction could contribute to the emergence of stress-related disorders.

\section{Materials and methods}

Animals

Transgenic mice overexpressing neural CRF were generated as described previously (Dirks et al. 2002). Briefly, the CRF transgene was composed of the complete coding sequence of rat CRF cDNA (.6-kb fragment), which was inserted into an 8.2-kb genomic DNA fragment encompassing the murine Thy-1.2 gene, including regulatory regions and polyadenylation signal sequence. The Thy-1 regulatory sequences drive constitutive transgene expression in postnatal and adult neurons. Subsequent breeding at the local breeding facilities (Utrecht, the Netherlands) consisted of matings between heterozygous transgenic males (C57BL/6J background) and C57BL/6JIco females (Charles River, the Netherlands).

Male transgenic CRF-overexpressing mice (15th generation) were used in these experiments. Littermate WT mice served as control mice. Animals were group-housed at constant room temperature $\left(21 \pm 2^{\circ} \mathrm{C}\right)$ and relative humidity (50-60\%) with PVC tubing as cage enrichment. Standard rodent food pellets (Special Diet Services, Witham, Essex, United Kingdom) and water were freely available. Mice were maintained on a 12-h light-dark cycle (lights on at $6 \mathrm{AM})$. All experiments were performed in accordance with the governmental guidelines for care and use of laboratory animals and approved by the Ethical Committee for Animal Research of the Faculties of Sciences, Utrecht University, The Netherlands.

\section{Drugs}

Diazepam (base) and zolpidem (tartaric acid salt) were obtained from Sigma Aldrich. MPEP HCl (2-methyl-6(phenylethynyl)pyridine) and MTEP (3-((2-methyl-4-thiazolyl)ethynyl)pyridine) were obtained from Alexis Biochemicals. LY379268 (1R,4R,5S,6R)-2-oxa-4-aminobicyclo [3.1.0]hexane-4,6-dicarboxylate) was obtained from Tocris. $\mathrm{SH}-053-2 \mathrm{~F}-\mathrm{R}-\mathrm{CH}_{3}$ (the $(R)$ stereoisomer of 8-ethynyl-4methyl-6-phenyl-4H-2,5,10b-triaza-benzo[e]azulene-3-carboxylic acid ethyl ester) was synthesized by the laboratory of Dr. J.M. Cook (University of Wisconsin-Milwaukee, USA). TP003 (4,2'-dufluoro-5'-[8-fluoro-7-(1-hydroxy-1, methylethyl)imidazo[1,2-a]pyridin-3-yl]biphenyl-2-carbonitrile) was synthesized according to published methods (Dias et al. 2005; Humphries et al. 2006). CP154,526 HCl (butyl-ethyl-[2,5-dimethyl-7-(2,4,6-trimethylphenyl)-7Hpyrrolo $[2.3-d]$ pyrimidin-4-yl]amine) and DMP695 mesy- 
late (N-(2-chloro-4,6-dimethylphenyl)-1-[1-methoxymethyl-(2-methoxyethyl]-6-methyl-1H-1,2,3,triazolo[4,5-c] pyridin-4-amine) were gifts from Institut de Recherche, Servier, Croissy/Seine France. An injection volume of $10 \mathrm{ml} / \mathrm{kg}$ was used for intraperitoneal injections of all drugs. All drugs were suspended in gelatine-mannitol $0.5 \% / 5 \%$. Fresh solutions and suspensions were prepared each testing day.

The stress-induced hyperthermia procedure

The SIH procedure was carried out according to standard procedures (Groenink et al. 2009). Briefly, animals $(n=10-13)$ were injected intraperitoneally with vehicle or drug $60 \mathrm{~min}$ before the first temperature measurement $\left(T_{1}\right)$. The temperature was again measured $10 \min$ later $\left(T_{2}\right)$, representing the stress-induced body temperature. The stress-induced hyperthermia response was calculated by subtracting $T_{1}$ from $T_{2}$. A within-subject design was used, and cages were randomly and evenly allocated. The body temperature of mice was measured by rectally inserting a thermistor probe by a length of $2 \mathrm{~cm}$. Digital temperature recordings were obtained with an accuracy of $0.1^{\circ} \mathrm{C}$ using a Keithley $871 \mathrm{~A}$ digital thermometer (NiCr-NiAl thermocouple). The probe, dipped into silicon oil before inserting, was held in the rectum until a stable rectal temperature had been obtained for $20 \mathrm{~s}$.

\section{Quantitative PCR analysis}

$\mathrm{GABA}_{\mathrm{A}}$ receptor subunit levels as well as mGlu receptor mRNA levels were determined in drug-naïve wildtype and transgenic mice. Mice were decapitated, brains were removed and stored at $-80^{\circ} \mathrm{C}$ until further use. Sections of $0.5 \mathrm{~mm}$ were made using a cryostat and were kept frozen while the hypothalamus and amygdala were dissected under a binocular microscope. We chose to study the hypothalamus and amygdala for mRNA expression because these brain areas have been shown to be pivotal in the autonomic stress responses such as the stress-induced hyperthermia response (Ulrich-Lai and Herman 2009; Vinkers et al. 2008). Tissue samples were homogenized in Trizol reagent (Invitrogen, the Netherlands) followed by a clean-up with NucleoSpin ${ }^{\circledR}$ RNA Clean-up XS (Machery Nagel, Germany). Reverse transcriptase was performed using the RevertAid ${ }^{\mathrm{TM}}$ kit (Fermentas, Germany) and an oligo(dT) primer. The following protocol was used for all PCR reactions, carried out in 20- $\mu$ l reactions in an ABI PRISM 700 (Applied Biosystems, the Netherlands): 15 min at $95^{\circ} \mathrm{C}$, followed by 40 cycles consisting of $15 \mathrm{~s}$ at $95^{\circ} \mathrm{C}$ and $60 \mathrm{~s}$ at $60^{\circ} \mathrm{C}$. Each reaction mix contained $0.1 \mu \mathrm{M}$ of each of the gene specific primers and ABsolute ${ }^{\mathrm{TM}}$ QPCR SYBR ${ }^{\circledR}$ Green mix (Abgene, Epsom, United Kindom). The efficiency of a given PCR reaction was determined using five two-fold dilutions of a mixture of the obtained cDNA samples. Each reaction had an efficiency close to $100 \%$. Measured cDNA levels were normalized against the levels of GAPDH. The following primers were used (FP, RP): GAPDH (GCACCCTGCATTATTTTGTCA, CTTCCAGGAGCGAGACCCCA), GABA $A_{A}$ receptor $\alpha_{1}$ subunit (CCACACCCCATCAATAGGTTCT, AATTCT CGGTGCAGAGGACTGAA), GABA A receptor $\alpha_{2}$ subunit (GGGACGGGAAGAGTGTAGTCAA, CCGCATA GGCGTTGTTCTGT), GABA $A$ receptor $\alpha_{3}$ subunit (GC CCACTGAAGTTTGGAAGCTAT, CATCCTGTGCTAC TTCCACAGATT), GABA $A$ receptor $\alpha_{5}$ subunit (GCCC AGAGAGTCTCTGGAGCT,GGGCCACCTCTCCAA AGTAAAC), mGlur2 receptor (AACCTTGGTCAAGGG TCTG, AAGCGACGATGTTGTTGAG), mGlur3 receptor (CCTGGATGGAAAGAAGTTG, TTGAATGGAGCTGT GAAG), and the mGlur5 receptor(TACTTCTGGGCAGT GATG, GACAGCTTCTCGCTGATAC).

\section{Data analysis}

For SIH experiments, a basal temperature $\left(T_{1}\right)$, an end temperature $\left(T_{2}\right)$, and the difference $\left(\mathrm{SIH}\right.$ response $\left.=T_{2}-T_{1}\right)$ was determined for each individual mouse. Treatment effects on the SIH response and basal body temperature $\left(T_{1}\right)$ were evaluated using a repeated-measures analysis of variance with "drug" as within-subject factor and "genotype" as between-subject factor. For post-hoc comparisons, Dunnett's $t$ tests were applied. mRNA levels were analyzed using a univariate analysis of variance with genotype (WT/ CRF-OE) as a fixed factor. A probability level of $p<0.05$ was set as statistically significant.

\section{Results}

CP154,526 (0-40 mg/kg, IP)

CP154,526 affected the SIH response differently in WT animals compared to CRF-OE mice (CP154,526× genotype interaction $F_{3,60}=3.60, p<0.05$ ) (Fig. 1b). Separate analysis of the genotypes revealed that CP154,526 reduced the SIH response in WT animals $\left(F_{3,33}=8.12, p<0.001\right)$ but not in CRF-OE animals $\left(F_{3,30}=\right.$ $2.59, p=0.11)$. In WT animals, post hoc analysis showed that this effect was attributable to the 10 and $20 \mathrm{mg} / \mathrm{kg}$ doses of CP154,526.

CP154,526 lowered basal body temperature regardless of genotype (CP154,526 effect $F_{3,60}=38.57, p<0.01$; CP154,526 $\times$ genotype interaction, $F_{3,60}=0.54, p=0.66$, NS; genotype effect $F_{1,20}=0.66, p=0.43$, NS) (Fig. 1a). Post hoc analysis revealed that this effect was significant only at the $40 \mathrm{mg} / \mathrm{kg}$ dose of CP154,526. 
Fig. 1 Effects of the $\mathrm{CRF}_{1}$ receptor antagonists $\mathrm{CP} 154,526$ $(0-40 \mathrm{mg} / \mathrm{kg}, \mathrm{IP}, \mathbf{a}-\mathbf{b})$ and DMP $695(0-40 \mathrm{mg} / \mathrm{kg}, \mathrm{IP}, \mathbf{c}-\mathbf{d})$ on basal body temperature and the SIH response in wildtype mice (WT) and CRF-overexpressing mice (CRF-OE). Asterisk drug effect relative to vehicle $(* p<0.05 ; * * p<0.01)$
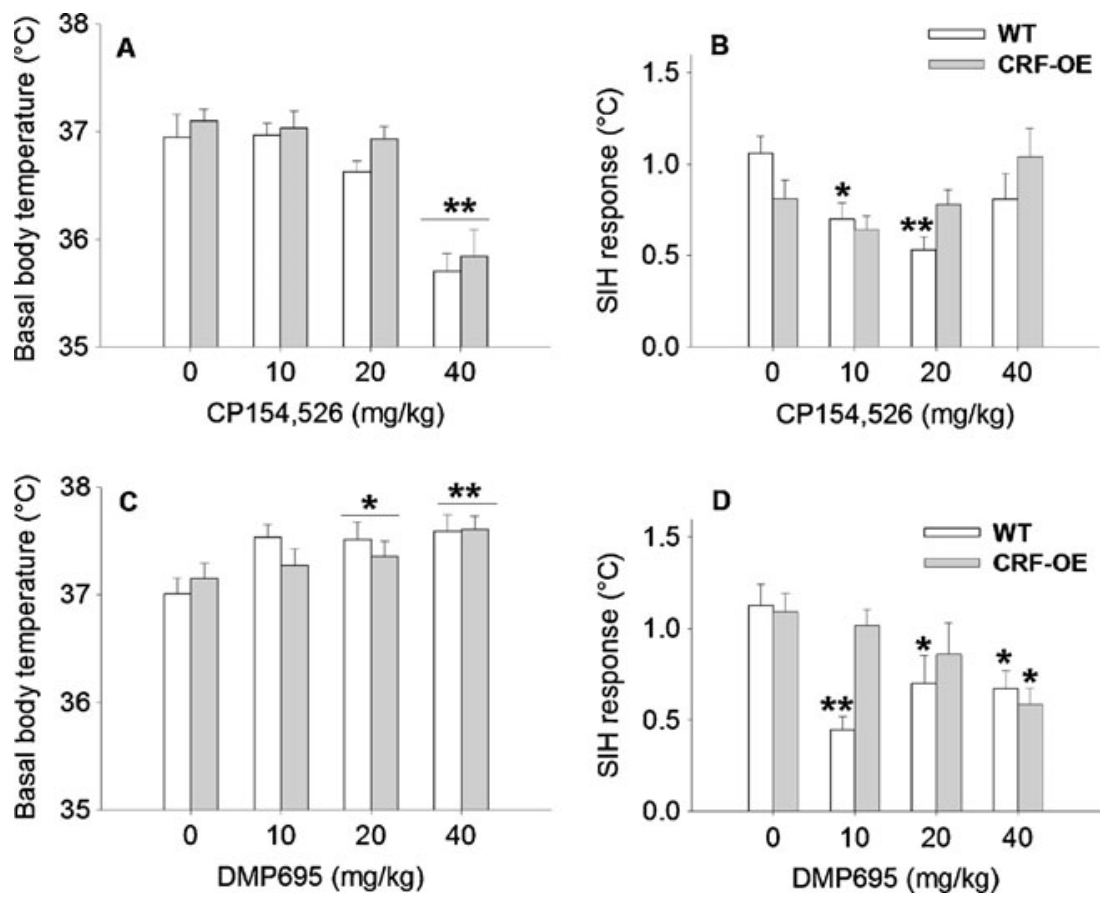

DMP695 (0-40 mg/kg, IP)

DMP695 reduced the SIH response to a larger extent in WT animals compared to CRF-OE mice (DMP695 $\times$ genotype interaction $F_{3,63}=5.63, p<0.01$ ) (Fig. 1d). Separate analysis of the genotypes showed that DMP695 reduced the SIH response in WT animals $\left(F_{3,30}=10.41, p<0.01\right)$ as well as CRF-OE animals $\left(F_{3,33}=6.26, p<0.01\right)$. Post hoc analysis indicated that in WT mice, all DMP695 doses significantly reduced the SIH response, whereas in CRF-OE animals, only the highest dose of DMP695 reduced the SIH response.

DMP695 increased body temperature regardless of genotype (DMP695 effect $F_{3,63}=6.33, p<0.01$; DMP695× genotype interaction, $F_{3,63}=1.07, p=0.37$, NS) (Fig. 1c). Post hoc analysis revealed that compared to vehicle, this increase was significant at the 20 and $40 \mathrm{mg} / \mathrm{kg}$ doses of DMP695.

\section{Diazepam (0-4 mg/kg, IP)}

The hypothermic effect of diazepam was dependent on genotype (diazepam $\times$ genotype interaction, $F_{3,63}=2.77$, $p<0.05$ ) (Fig. 2a). Separate analysis of the genotypes indicated that diazepam reduced basal body temperature in WT animals $\left(F_{3,36}=7.77, p<0.001\right)$ but not in CRF-OE animals $\left(F_{3,27}=0.10, p=0.96\right.$, NS). In WT animals, post hoc analysis showed that only the $4 \mathrm{mg} / \mathrm{kg}$ dose of diazepam significantly reduced basal body temperature.

Diazepam reduced the SIH response regardless of genotype (diazepam effect $F_{3,63}=17.25, p<0.001$; diaze- pam $\times$ genotype interaction $F_{3,63}=0.17, p=0.92, \mathrm{NS}$; genotype effect $F_{1,21}=0.03, p=0.86$, NS) (Fig. 2b). Post hoc analysis revealed that diazepam significantly reduced the $\mathrm{SIH}$ response at all doses compared to vehicle.

Zolpidem (0-10 mg/kg, IP)

Zolpidem affected the SIH response regardless of genotype (zolpidem effect $F_{2,40}=5.21, p=0.01$; zolpidem $\times$ genotype interaction $F_{2,40}=0.52, p=0.60$, NS; genotype effect $F_{1,20}=$ $0.17, p=0.69$, NS) (Fig. 2d). Post hoc analysis showed that zolpidem reduced the SIH response only at the $10 \mathrm{mg} / \mathrm{kg}$ dose.

Zolpidem reduced basal body temperature more in WT animals than in CRF-OE mice (zolpidem $\times$ genotype interaction, $F_{2,40}=6.39, p<0.01$ ) (Fig. 2c). Separate analysis of the genotypes showed that zolpidem reduced basal body temperature in WT animals $\left(F_{2,22}=27.86, p<0.001\right)$ as well as in CRF-OE animals $\left(F_{2,18}=21.93, p<0.001\right)$. Post hoc analysis showed that in WT animals, all zolpidem doses had a strong hypothermic effect, whereas in CRF-OE animals, only the $10 \mathrm{mg} / \mathrm{kg}$ dose of zolpidem significantly induced hypothermia.

TP003 (0-3 mg/kg, IP)

TP003 reduced the SIH response, and a trend for a genotype effect was present (TP003 effect $F_{3,60}=5.42$, $p<0.01$; TP003 $\times$ genotype interaction $F_{3,60}=1.99, p=0.09$ ) (Fig. 2f). Separate analysis of the genotypes showed that TP003 reduced the SIH in WT animals $\left(F_{3,33}=5.16, p<0.01\right)$ 
Fig. 2 Effects of the nonsubunit selective $\mathrm{GABA}_{\mathrm{A}}$ receptor agonist diazepam $(0-4 \mathrm{mg} / \mathrm{kg}, \mathrm{IP}, \mathbf{a}-\mathbf{b})$, the preferential $\alpha_{1}$ subunit GABA receptor agonist zolpidem (0-10 mg/kg, IP, c-d), the $\mathrm{GABA}_{\mathrm{A}}$ receptor $\alpha_{3}$ subunit agonist TP003 (0-3 mg/kg, IP, e-f) and the $\mathrm{GABA}_{\mathrm{A}}$ receptor $\alpha_{5}$ subunit agonist SH-053-2'FR- $\mathrm{CH}_{3}(0-30 \mathrm{mg} / \mathrm{kg}, \mathrm{IP}, \mathbf{g}-\mathbf{h})$ on basal body temperature and the stress-induced hyperthermia (SIH) response in wildtype (WT) and CRF-overexpressing mice (CRF-OE). Asterisk drug effect relative to vehicle $\left({ }^{*} p<0.05 ; * * p<0.01\right.$; $* * * p<0.001)$
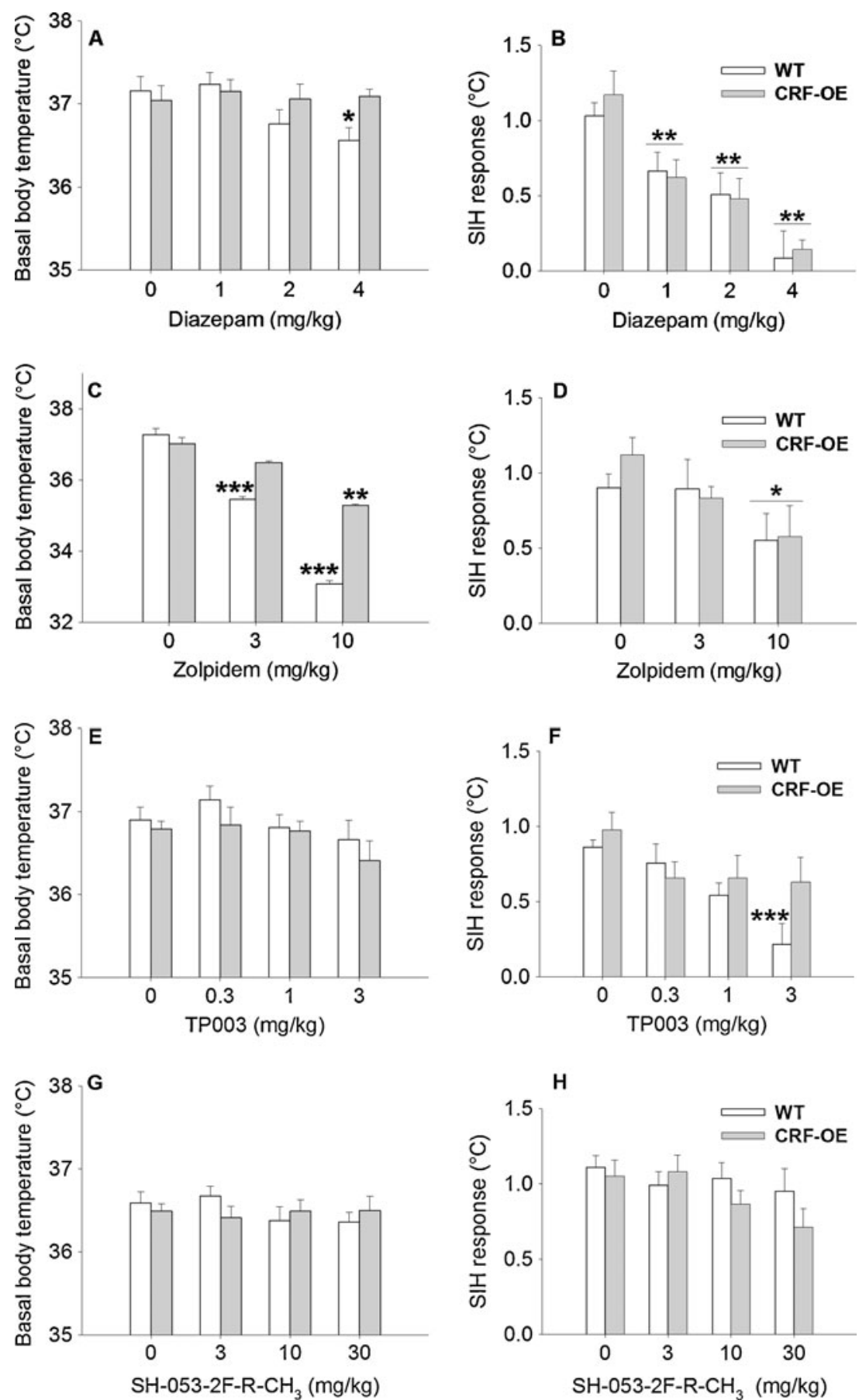

but not in CRF-OE animals $\left(F_{3,27}=1.84, p=0.16\right.$, NS). Post hoc analysis indicated that in WT animals, only the $3 \mathrm{mg} / \mathrm{kg}$ dose of TP003 significantly reduced the SIH response.

TP003 reduced basal body temperature regardless of genotype (TP003 effect $F_{3,60}=3.21, p<0.05$; TP003× genotype interaction, $F_{3,60}=0.36, p=0.78$, NS; genotype effect $F_{1,20}=1.41, p=0.25$, NS) (Fig. 2e). After post hoc analysis, it appeared that this effect was not significant at any separate TP003 dose.
SH-053-2'F-R-CH $3(0-30 \mathrm{mg} / \mathrm{kg}$, IP)

SH-053-2' $\mathrm{F}-\mathrm{R}-\mathrm{CH}_{3}$ did not affect the SIH response regardless of genotype (SH-053-2'F-R-CH ${ }_{3}$ effect $F_{3,60}=2.03, p=0.12$, NS; SH-053-2'F-R-CH ${ }_{3} \times$ genotype interaction $F_{3,60}=0.67, p=$ 0.57 , NS; genotype effect $F_{1,20}=0.36, p=0.56$, NS) (Fig. $2 \mathrm{~h}$ ).

SH-053-2'F-R-CH ${ }_{3}$ did not affect body temperature (SH$053-2^{\prime} \mathrm{F}-\mathrm{R}-\mathrm{CH}_{3}$ effect $F_{3,60}=0.76 p=0.52$, NS; SH-053-2'FR- $\mathrm{CH}_{3} \times$ genotype interaction, $F_{3,60}=1.20, p=0.32$, NS; genotype effect $F_{1,20}=0.08, p=0.78$, NS) (Fig. 2g). 
MPEP $(0-30 \mathrm{mg} / \mathrm{kg}, \mathrm{IP})$

MPEP reduced the SIH response regardless of genotype (MPEP effect $F_{3,63}=16.55, p<0.001$; MPEP $\times$ genotype interaction $F_{3,63}=0.31, p=0.82$, NS; genotype effect $F_{1,21}=0.95$, $p=0.34$, NS) (Fig. 3b). Post hoc analysis indicated that MPEP significantly reduced the SIH response at the 10 and $30 \mathrm{mg} / \mathrm{kg}$ doses compared to vehicle-treated mice.

MPEP increased body temperature regardless of genotype (MPEP effect $F_{3,63}=5.63, p<0.01$; MPEP $\times$ genotype interaction, $F_{3,63}=0.65, p=0.58$, NS; genotype effect $F_{1,21}=1.66, p=0.21$, NS) (Fig. 3a). Post hoc analysis revealed that this difference was significant at the $30 \mathrm{mg} / \mathrm{kg}$ MPEP dose.

\section{MTEP $(0-30 \mathrm{mg} / \mathrm{kg}$, IP)}

MTEP reduced the SIH response regardless of genotype (MTEP $\times$ genotype interaction $F_{3,63}=0.03, p=0.99$, NS; MTEP effect $F_{3,63}=21.87, p<0.001$; genotype effect $F_{1,21}=0.04$, $p=0.85$, NS) (Fig. 3d). Post hoc analysis showed that MTEP significantly reduced the SIH response at all doses compared to vehicle-treated mice.

MTEP overall reduced body temperature regardless of genotype (MTEP effect $F_{3,63}=19.04, p<0.001$; MTEP $\times$ genotype interaction, $F_{3,63}=0.42, p=0.74$, NS; genotype effect $F_{1,21}=0.42, p=0.53$, NS) (Fig. $3 c$ ). Post hoc analysis showed that this effect was significant at the $30 \mathrm{mg} / \mathrm{kg}$ MTEP dose $(p<0.001)$.

\section{LY379268 (0-10 mg/kg, IP)}

The effect of LY379268 on the SIH response was dependent on the genotype in which it was tested (LY379268 $\times$ genotype interaction $F_{3,60}=3.08, p<0.05$ ) (Fig. 3f). Separate analysis of the genotypes showed that LY379268 reduced the SIH in WT animals $\left(F_{3,27}=8.85, p<0.001\right)$ but not in CRF-OE animals $\left(F_{3,27}=2.30, p=0.14, \mathrm{NS}\right)$. Post hoc analysis indicated that in WT mice, the 3 and $10 \mathrm{mg} / \mathrm{kg}$ LY3792368 doses significantly reduced the SIH response.
Fig. 3 Effects of the mGluR $_{5}$ antagonists MPEP $(0-30 \mathrm{mg} / \mathrm{kg}$, IP, a-b), MTEP (0-30 mg/kg, IP, c-d) and the $\mathrm{mGluR}_{2 / 3}$ agonist LY379268 (0-10 mg/kg, IP, e-f), on basal body temperature and the stress-induced hyperthermia (SIH) response in wildtype (WT) and CRF-overexpressing mice (CRF-OE). Asterisk drug effect relative to vehicle $\left({ }^{*} p<0.05 ; * * p<0.01\right.$; $* * * p<0.001)$
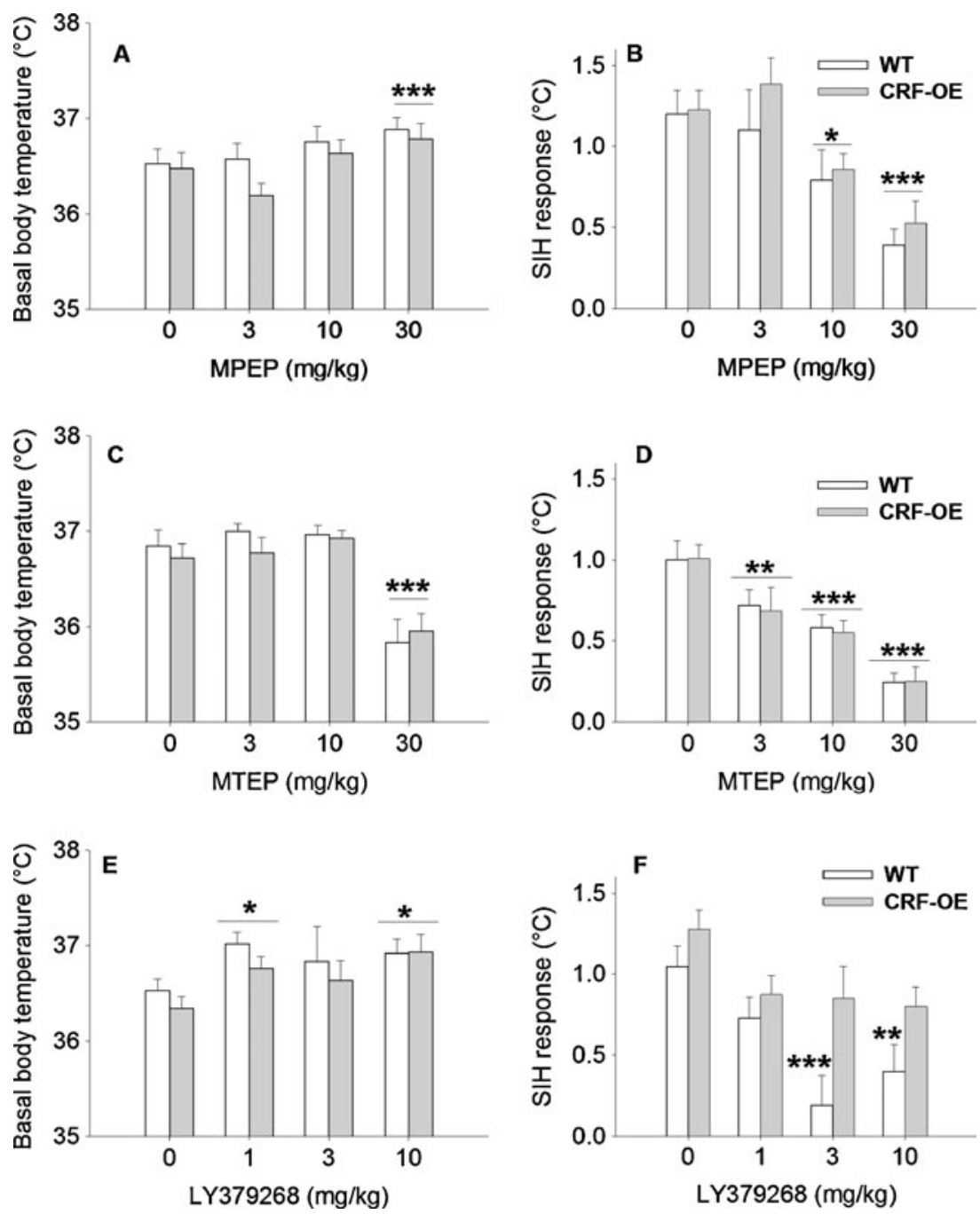
LY379268 increased body temperature regardless of genotype (LY379268 effect $F_{3,60}=3.59, p<0.05$; LY379268 $\times$ genotype interaction, $F_{3,60}=0.22, p=0.89$, NS; genotype effect $F_{1,21}=0.81, p=0.38$, NS) (Fig. 3e). Post hoc analysis revealed that this effect was significant at the 1 and $10 \mathrm{mg} / \mathrm{kg}$ doses of LY379268.

Quantitative PCR analysis

Results of the PCR analysis showed increased $\mathrm{GABA}_{\mathrm{A}} \mathrm{R}$ $\alpha_{1}, \alpha_{2}, \alpha_{5}$ subunit, and mGluR $_{3}$ mRNA levels in the hypothalamus in CRF-overexpressing group, whereas no changes were found in $\alpha_{3}$ subunit, $\mathrm{mGluR}_{2}$, and $\mathrm{mGluR}_{5}$ mRNA levels (Fig. 4a). In contrast, decreased GABA ${ }_{A} R \alpha_{2}$ subunit and $\mathrm{mGluR}_{3}$ mRNA levels were present in the amygdala of CRF-overexpressing mice compared to WT mice (Fig. 4b). All mRNA levels were normalized against levels of GAPDH.

\section{Discussion}

The present studies investigated the putative link between chronically elevated CRF levels and subsequent alterations in $\mathrm{GABA}_{\mathrm{A}}$ and glutamate receptor responsivity using transgenic mice that overexpress $\mathrm{CRF}$ in the brain. To this end the effect of $\mathrm{CRF}_{1}$ receptor, $\mathrm{GABA}_{\mathrm{A}} \mathrm{R}$, and $\mathrm{mGLuR}$ ligands were studied in the SIH test. In WT mice, the $\mathrm{CRF}_{1}$ receptor antagonists CP154,526 and DMP695 reduced the SIH response, which is indicative for an anxiolytic effect of these compounds (Kehne and Cain 2010; Millan et al. 2001; Zorrilla and Koob 2010). The fact that DMP695 induced a mild hyperthermia of around $0.5^{\circ} \mathrm{C}$ most probably did not interfere with the capability to induce a $\mathrm{SIH}$ response because stress-induced rectal temperature is capable of rising over $39^{\circ} \mathrm{C}$, and is even present in interleukin-induced fever (Vinkers et al. 2009a). Our data confirm previous anxiolytic effects of the $\mathrm{CRF}_{1}$ receptor antagonist SSR125543A using the SIH paradigm (Griebel et al. 2002). In contrast to the effects observed in WT animals, CRF-OE mice showed an impaired anxiolytic response to the $\mathrm{CRF}_{1}$ receptor antagonists $\mathrm{CP} 154,526$ and DMP695 (Fig. 1). However, no apparent rightward shift in responsivity to $\mathrm{CRF}_{1}$ receptor antagonists was found, suggesting that elevated CRF levels do not induce a straightforward receptor desensitization or downregulation. In fact, there is evidence that no prominent CRF receptor mRNA downregulation is present in CRF-OE mice (Korosi et al. 2006). Impaired sensitivity to $C_{R F}$ receptor antagonists in CRF-OE mice could also be explained by a more brain-structure-specific change of CRF receptor distribution in these mice, with decreased $\mathrm{CRF}_{1}$ receptor mRNA and increased $\mathrm{CRF}_{2}$ receptor mRNA in specific
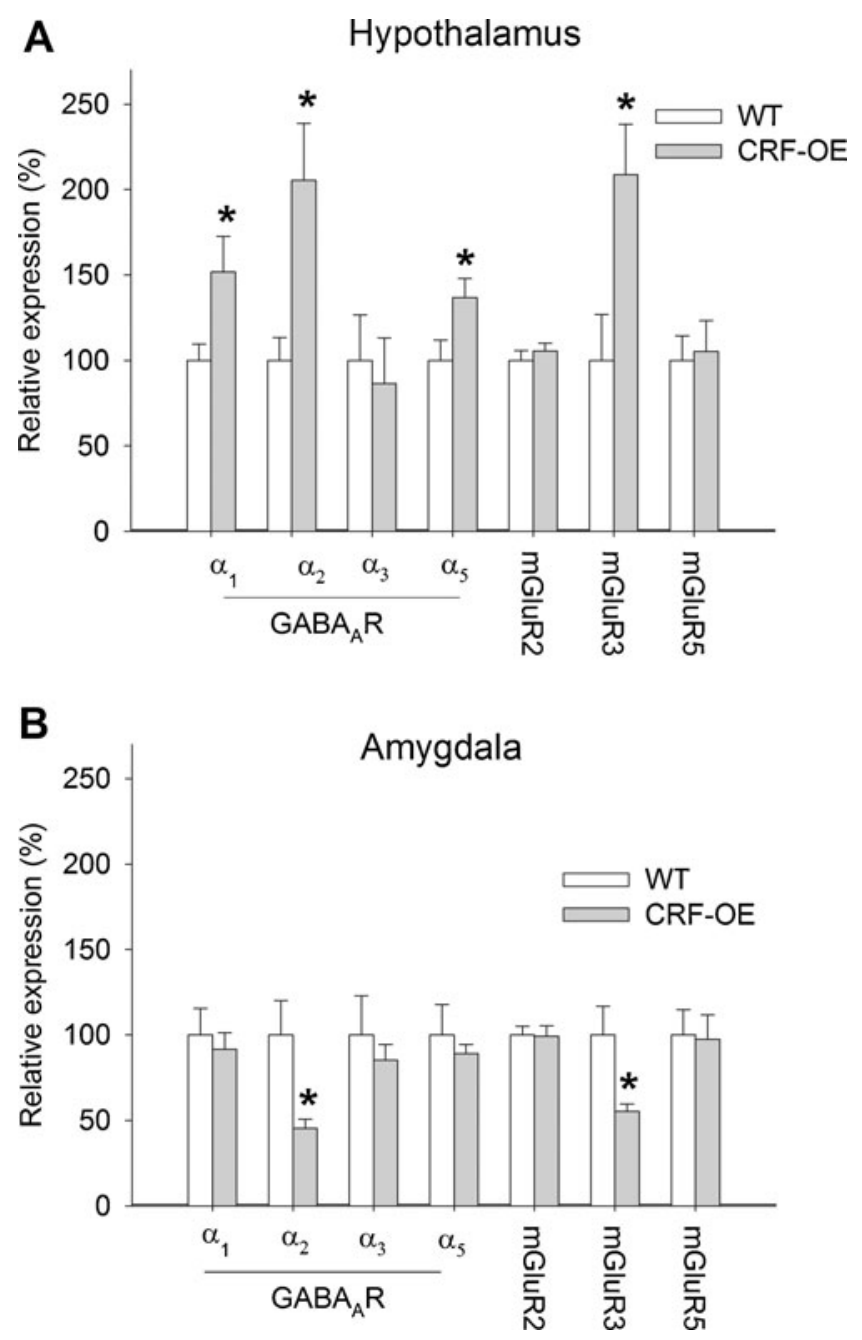

Fig. 4 mRNA levels of $\mathrm{GABA}_{\mathrm{A}}$ receptor subunits and mGlur receptors (mean $\pm \mathrm{SEM}$ ) in the hypothalamus a and the amygdala $\mathbf{b}$ of wildtype (WT) on CRF-overexpressing mice (CRF-OE) mice. The mRNA expression was normalized against GAPDH level. ${ }^{*} p<0.05$

brain structures (Korosi et al. 2006). Irreversible and specific changes in the CRF system in CRF-OE mice seem to contrast with the fact that prepulse inhibition deficits in these animals are readily reversed after administration of $\mathrm{CRF}_{1}$ receptor antagonists (Groenink et al. 2008). However, a possible caveat is that these PPI deficits - in contrast to anxiety-related processes - are only present during lasting activation of CRF receptors (Bijlsma et al. 2011). Here, $\mathrm{CRF}_{1}$ receptor antagonists either decreased $(\mathrm{CP} 154,526)$ or increased basal body temperature (DMP695). We do not have a good explanation for this difference as both drugs show high affinity for human $(\mathrm{h}) \mathrm{CRF}_{1}\left(K_{\mathrm{i}}, 3.3 \mathrm{nM}\right)$ and native rat $\mathrm{CRF}_{1}\left(K_{\mathrm{i}}, 4.6 \mathrm{nM}\right)$ receptors and low affinity for $\mathrm{CRF}_{2} \alpha$ and other classes of receptors (Millan et al. 2001). Possible explanations include reduced bioavailability of CP154-526, or partial agonist activity at and differential involvement of various $\mathrm{CRF}_{1}$ receptor isoforms and 
binding sites. These drug-induced changes in basal body temperature were similar across both genotypes, and basal body temperature was comparable between WT and CRF$\mathrm{OE}$ mice, suggesting that the role of $\mathrm{CRF}_{1}$ receptors in stress-induced hyperthermia is different from that in basal thermoregulatory processes. Acute central CRF administration increases basal body temperature, suggesting that the CRF system may directly affect thermoregulatory processes (Heinrichs et al. 2001). Although Dirks and colleagues reported increased body temperature in CRF-OE mice in the late afternoon (maximum $0.5^{\circ} \mathrm{C}$ ) in CRF-OE mice (Dirks et al. 2002), we found no overall effects of genotype on basal body temperature. This is probably due to the fact that the present experiments were carried out between $9 \mathrm{AM}$ and $2 \mathrm{PM}$, whereas body temperature in CRF-OE mice was only found to be moderately increased from 2-5 PM.

Chronic CRF overproduction not only resulted in reduced sensitivity to the anxiolytic effects of $\mathrm{CRF}_{1}$ receptor antagonists, but also in reduced sensitivity to the anxiolytic effects of the $\mathrm{GABA}_{\mathrm{A}} \mathrm{R} \alpha_{2 / 3}$ subunit-selective agonist TP003 (Dias et al. 2005) and the $\mathrm{mGlu}_{2 / 3} \mathrm{R}$ agonist LY379268. Both TP003 and LY379268 reduced the SIH response to a lesser extent in CRF-OE animals than in WT mice but did not result in hypothermia. The SIH-reducing effect of these compounds is in line with known anxiolytic effects of both $\alpha_{2 / 3}$ selective GABAergic modulators (Atack 2010; Dias et al. 2005; Mirza et al. 2008) and mGluR (ant)agonists (Niswender and Conn 2010). We also report that the hypothermic effect of the non-selective $\mathrm{GABA}_{\mathrm{A}} \mathrm{R}$ agonist diazepam and the $\alpha_{1}$-selective GABA $\mathrm{R}$ agonist zolpidem (Petroski et al. 2006) were less pronounced in CRF-OE than in WT mice (Fig. 2). The impaired GABAergic and glutamatergic sensitivity in CRF-OE mice appeared to be specific, as genotype did not affect responsivity to the $\alpha_{5}$-subunit preferential $\mathrm{GABA}_{\mathrm{A}}$ receptor agonist SH-053-2'F-R-CH (Fig. 2) or the $\mathrm{mGluR}_{5}$ antagonists MPEP and MTEP (Fig. 3). In contrast to our results, previous studies did not show a significant increase of basal body temperature after administration of MPEP up to oral doses of $30 \mathrm{mg} / \mathrm{kg}$ in mice (Nordquist et al. 2007; Spooren et al. 2002; Spooren et al. 2000). However, the MPEP-induced hyperthermia is minor with a maximum MPEP-induced hyperthermia of around $0.3^{\circ} \mathrm{C}$ occurring at the highest dose. In support, MPEPinduced basal body temperature as reported by Spooren and colleagues display an apparent trend for body temperature increases although this does not reach statistical significance (Spooren et al. 2000). In support, we administered MPEP intraperitoneally (compared to oral administration in the other studies), leading to increased CNS drug levels. Moreover, the present study used a within-subject design which may be more sensitive to result in statistical significance.
Our results confirm and extend the SIH-reducing effects of (non-)selective GABAergic modulators diazepam, zolpidem, and TP003 (for review, see (Vinkers et al. 2010b)) as well as those of the glutamatergic compounds $\left(\mathrm{mGluR}_{2 / 3}\right.$ agonists and $\mathrm{mGluR}_{5}$ antagonists) (Nordquist et al. 2007; Spooren et al. 2002). The fact that the $\alpha_{5}$-subunit preferential $\mathrm{GABA}_{\mathrm{A}}$ receptor agonist $\mathrm{SH}-053-2^{\prime} \mathrm{F}-\mathrm{R}-\mathrm{CH}_{3}$ did not affect basal body temperature nor the SIH response compared to vehicle-treated mice may suggest that the $\alpha_{5}$ subunit is not involved in the anxiolytic and hypothermic effects of benzodiazepines, which is in line with the already published findings (Atack 2011; Rudolph and Mohler 2006; Savic et al. 2010). However, the use of $\alpha_{5}$-selective (silent) antagonists is warranted to further characterize the role of this subunit in hypothermia and anxiolysis.

Long-lasting CRF hyperactivity is thus associated with a decreased GABAergic and glutamatergic receptor sensitivity at adult age. In our results, either the SIH response (TP003 and LY379268) or basal body temperature (diazepam and zolpidem) were affected in CRF-OE mice, suggesting that neurocircuitry involved in these processes may have adapted in these transgenic mice. These results may indicate that a blunted SIH attenuation without concomitant basal body temperature differences reflect specific dysfunction involving stress-related circuitry in CRF-OE animals. In support, basal body temperature and the autonomic stress response have been found to be regulated independently with a putative role for the $\mathrm{GABA}_{\mathrm{A}} \mathrm{R} \alpha_{1}$ subunit in basal thermoregulation and a role for $\alpha_{2}$ and $\alpha_{3}$ subunits in the SIH response (Vinkers et al. $2009 b$ ). Our current results are in the line with such a distinction in $\alpha$ subunit function in the SIH paradigm.

Besides alterations in functional receptor sensitivity, CRF-OE mice display molecular alterations in $\mathrm{GABA}_{\mathrm{A}} \mathrm{R}$ and mGluR circuitry in the amygdala and hypothalamus. These brain areas were chosen since they have been shown to be pivotal in autonomic stress responsivity (Ulrich-Lai and Herman 2009; Vinkers et al. 2010a; Vinkers et al. 2008). Also, central thermoregulation is eventually regulated in the hypothalamus, and a connection between the anxiety-involved limbic system and the hypothalamic temperature execution areas is generally assumed (Dimicco and Zaretsky 2007). Amygdaloid $\mathrm{GABA}_{\mathrm{A}} \mathrm{R} \alpha_{2}$ subunit and mGluR $_{3}$ mRNA levels were decreased in CRF-OE mice (Fig. 4), whereas opposing effects were found in the hypothalamus. The hypothalamic increase in $\alpha_{5}$ subunit expression may reflect a compensatory mechanism in which changes in $\alpha_{5}$-dependent GABAergic transmission would lead to increased tonic (extra)synaptic activity (Caraiscos et al. 2004). In support, chronic administration of anabolic androgenic steroids which can affect mood and induce anxiety also resulted in increased mRNA expression of the $\alpha_{5}$ subunit in the hypothalamus, (Penatti et al. 2009). 
Moreover, chronic stress led to up-regulation of the $\alpha_{5}$ subunit expression in the hypothalamic paraventricular nucleus (Verkuyl et al. 2004). Surprisingly, the impaired sensitivity to the $\mathrm{GABA}_{\mathrm{A}} \mathrm{R} \alpha_{3}$ subunit-selective agonist TP003 was not accompanied by changes in $\alpha_{3}$ subunit mRNA expression. This may be due to the fact that $\alpha_{3}$ subunit expression is relatively low in the amygdala and hypothalamus. The expression of the $\alpha_{3}$ subunit is highest in the cortex, hippocampus, thalamus, and brainstem (including monoaminergic neurons such as the raphe nuclei and the locus coeruleus) (Mohler et al. 2002). Also, the $\alpha_{3}$ selective nature of TP003 can be questioned. Although TP003 appears to possess somewhat lower in vitro efficacy for the $\alpha_{2}$ subunit compared to the $\alpha_{3}$ subunit (Dias et al. 2005), these differences may not be so pronounced in vivo. Moreover, subtype selective GABA compounds that distinguish between the $\alpha_{2}$ and the $\alpha_{3}$ subtype have not been developed yet (Atack 2010). Together, TP003 may prove to be functionally $\alpha_{2 / 3}$ subtype selective rather than $\alpha_{3}$ selective. In support of specific changes in $\alpha$ subunits, mRNA expression of the $\gamma_{2}$ subunit was not altered in the hypothalamus and amygdala of CRF-overexpressing mice compared to wildtype mice (data not shown). We did not investigate mRNA expression of other $\gamma$ subunits because the $\gamma_{1}$ and $\gamma_{3}$ subunits characterize a small population of $\mathrm{GABA}_{\mathrm{A}}$ receptors with a reduced affinity for classical benzodiazepines (McKernan and Whiting 1996).

The fact that CRF-OE mice display more subtle regionspecific differences in $\mathrm{CRF}_{1}$ and $\mathrm{CRF}_{2}$ receptor mRNA expression suggest that adaptations in the $\mathrm{GABA}_{\mathrm{A}}$ and glutamate receptor systems are probably not directly related to concomitant changes in CRF receptor expression (Korosi et al. 2006). The finding that chronic CRF exposure exerts opposing effects on hypothalamic and amygdaloid $\mathrm{GABA}_{\mathrm{A}} \mathrm{R}$ and $\mathrm{mGluR}_{3}$ mRNA levels may be the related to the differential effects of $\mathrm{CRF}_{1}$ and $\mathrm{CRF}_{2}$ receptors on the fast neurotransmitter systems. In support, $\mathrm{CRF}_{1}$ receptor activation in the amygdala decreased glutamate transmission, whereas $\mathrm{CRF}_{2}$ receptor activation opposed these $\mathrm{CRF}_{1}$ receptor-mediated effects on glutamate transmission (Liu et al. 2004). However, the applied methodology has important limitations. We cannot exclude the possibility that changes in the GABA and glutamate system are present in other brain regions of CRF-overexpressing mice such as the prefrontal cortex or the hippocampus. Also, no mRNA expression of amygdaloid and hypothalamic subnuclei was determined since punching out separate nuclei of these brain areas is technically very challenging in mice, and RNA isolation from extremely small tissue samples may suffer from the low input. Thus, our results do not pinpoint the exact subnuclei within the hypothalamus or amygdala that represent the overall changed gene expression. However, the observed changes are strong indications for changes in these areas that should be further explored using other methods such as immunohisochemistry or in situ hybridisation.

A number of studies support the notion that a disruption of the balance between glutamatergic excitation and GABAergic inhibition could underlie CRF-induced anxiety-like behavior. Repeated administration of urocortin, a CRF-related ligand into the basolateral amygdala induced long-lasting anxiety-like responses that were dependent on NMDA receptor activation but resulted in concomitant specific loss of $\mathrm{GABA}_{\mathrm{A}}$ receptor-mediated inhibition (Rainnie et al. 2004). Also, CRF enhanced $\mathrm{GABA}_{\mathrm{A}} \mathrm{R}$ inhibitory postsynaptic currents IPSCs in central amygdala neurons from wild-type and $\mathrm{CRF}_{2}$ receptor knockout mice but not $\mathrm{CRF}_{1}$ receptor knockout mice (Nie et al. 2004). In that study, $\mathrm{CRF}_{1}$ but not $\mathrm{CRF}_{2}$ receptor antagonists blocked these effects in wild type mice, a finding that was later confirmed using in vitro techniques (Bagosi et al. 2008). $\mathrm{CRF}$ enhanced $\mathrm{GABA}_{\mathrm{A}}$-mediated transmission via postsynaptic activation of $\mathrm{CRF}_{1}$ receptors in the bed nucleus of the stria terminalis (Kash and Winder 2006), and CRF has been shown to increase GABA release in the striatum (Sirinathsinghji and Heavens 1989). In serotonergic dorsal raphe neurons, CRF elevated presynaptic GABA release and increased $\mathrm{GABA}_{\mathrm{A}}$ receptor-mediated miniature IPSCs that were mediated by both $\mathrm{CRF}_{1}$ and $\mathrm{CRF}_{2}$ receptors (Kirby et al. 2008). In addition to CRF effects on the $\mathrm{GABA}_{\mathrm{A}}$ neurotransmission, Liu et al. (2004) showed concentration-dependent and opposing effects of CRF on fast excitatory glutamatergic transmission in the central nucleus of the amygdala and the lateral septum mediolateral nucleus. Moreover, CRF potentiated NMDA receptormediated excitation in the ventral tegmental area which was mediated by $\mathrm{CRF}_{2}$ receptors (Ungless et al. 2003). Although we found changes in mRNA expression levels that may suggest alterations at the receptor level associated with CRF overexpression, we cannot exclude the possibility that changes in GABAergic and glutamatergic neurotransmitter systems in CRF-OE mice may be the result of changes in intracellular signaling pathways. In support, $\mathrm{CRF}$ is implicated in protein kinase $\mathrm{C}$ and $\mathrm{Ca}^{2+} /$ calmodulin-dependent kinase II-dependent long-term neuronal potentiation and depression (Blank et al. 2003; Miyata et al. 1999), and CRF increases calcium currents in central amygdala neurons (Yu and Shinnick-Gallagher 1998). Also, CRF-induced changes could be mediated through the serotonergic system (Lukkes et al. 2008; Price et al. 1998; Tan et al. 2004). To our knowledge, no $\mathrm{GABA}_{\mathrm{A}}$ receptor subunit levels have been assessed in transgenic CRF mice lines or in rodents that have repeatedly been exposed to $\mathrm{CRF}$ or urocortin infusions.

In conclusion, we show that chronic CRF overproduction is accompanied by reduced functional $\mathrm{GABA}_{\mathrm{A}}$ and 
metabotropic glutamate $2 / 3$ receptor sensitivity in parallel with opposing changes in mRNA expression of these receptors in the amygdala and hypothalamus. These data provide evidence that CRF exerts a modulatory role on GABAergic and glutamatergic pathways in at least the amygdala and hypothalamus. Thus, these observations contribute to evidence linking an increased central CRF drive to the emergence of dysfunctional GABAergic and glutamatergic transmission which could play a role in stress-related disorders. Specifically, CRF-induced changes in activity at $\mathrm{GABA}_{\mathrm{A}} \mathrm{R} \alpha_{3}$ subunits and $\mathrm{mGlu}_{2 / 3}$ receptors may be of particular significance. If chronic CRF-induced changes in GABAergic and glutamatergic transmission contribute to the development of anxiety, depressed mood, drug-seeking, psychosis and other stress-related behavioral changes associated with sustained over-activation of CRF, ligands targeting specific classes of $\mathrm{GABA}_{\mathrm{A}}$ subunits and mGluR receptors may prove beneficial in the management of these disorders (Atack 2011; Millan 2003; Nicoletti et al. 2010; Yasuhara and Chaki 2011).

Conflicts of interest The authors declare no financial disclosures or conflicts of interest.

Open Access This article is distributed under the terms of the Creative Commons Attribution Noncommercial License which permits any noncommercial use, distribution, and reproduction in any medium, provided the original author(s) and source are credited.

\section{References}

Atack JR (2010) $\mathrm{GABA}_{\mathrm{A}}$ receptor subtype-selective modulators. I. alpha2/alpha3-selective agonists as non-sedating anxiolytics. Curr Top Med Chem 11:1176-202

Atack JR (2011) GABA $_{A}$ receptor alpha2/alpha3 subtype-selective modulators as potential nonsedating anxiolytics. Curr Top Behav Neurosci 2:331-360

Bagosi Z, Jaszberenyi M, Szabo G, Telegdy G (2008) The effects of CRF and the urocortins on $[3 \mathrm{H}] \mathrm{GABA}$ release from the rat amygdala - an in vitro superfusion study. Brain Res Bull $75: 15-17$

Bijlsma EY, van Leeuwen ML, Westphal KG, Olivier B, Groenink L (2011) Local repeated corticotropin-releasing factor infusion exacerbates anxiety- and fear-related behavior: differential involvement of the basolateral amygdala and medial prefrontal cortex. Neuroscience 173:82-92

Binder EB, Nemeroff CB (2010) The CRF system, stress, depression and anxiety-insights from human genetic studies. Mol Psychiatry $15: 574-588$

Blank T, Nijholt I, Grammatopoulos DK, Randeva HS, Hillhouse EW, Spiess J (2003) Corticotropin-releasing factor receptors couple to multiple G-proteins to activate diverse intracellular signaling pathways in mouse hippocampus: role in neuronal excitability and associative learning. J Neurosci 23:700-707

Bouwknecht JA, Olivier B, Paylor RE (2007) The stress-induced hyperthermia paradigm as a physiological animal model for anxiety: a review of pharmacological and genetic studies in the mouse. Neurosci Biobehav Rev 31:41-59

Caraiscos VB, Elliott EM, You-Ten KE, Cheng VY, Belelli D, Newell JG, Jackson MF, Lambert JJ, Rosahl TW, Wafford KA, MacDonald JF, Orser BA (2004) Tonic inhibition in mouse hippocampal CA1 pyramidal neurons is mediated by alpha5 subunit-containing gamma-aminobutyric acid type A receptors. Proc Natl Acad Sci U S A 101:3662-3667

Dias R, Sheppard WF, Fradley RL, Garrett EM, Stanley JL, Tye SJ, Goodacre S, Lincoln RJ, Cook SM, Conley R, Hallett D, Humphries AC, Thompson SA, Wafford KA, Street LJ, Castro JL, Whiting PJ, Rosahl TW, Atack JR, McKernan RM, Dawson GR, Reynolds DS (2005) Evidence for a significant role of alpha 3-containing $\mathrm{GABA}_{\mathrm{A}}$ receptors in mediating the anxiolytic effects of benzodiazepines. J Neurosci 25:10682-10688

Dimicco JA, Zaretsky DV (2007) The dorsomedial hypothalamus: a new player in thermoregulation. Am J Physiol Regul Integr Comp Physiol 292:R47-R63

Dirks A, Groenink L, Bouwknecht JA, Hijzen TH, Van Der Gugten J, Ronken E, Verbeek JS, Veening JG, Dederen PJ, Korosi A, Schoolderman LF, Roubos EW, Olivier B (2002) Overexpression of corticotropin-releasing hormone in transgenic mice and chronic stress-like autonomic and physiological alterations. Eur J Neurosci 16:1751-1760

Griebel G, Simiand J, Steinberg R, Jung M, Gully D, Roger P, Geslin M, Scatton B, Maffrand JP, Soubrie P (2002) 4-(2-Chloro-4methoxy-5-methylphenyl)- $N$-[(1S)-2-cyclopropyl-1-(3-fluoro-4methylphenyl)ethyl]5-methyl- $N$-(2-propynyl)-1, 3-thiazol-2amine hydrochloride (SSR125543A), a potent and selective corticotrophin-releasing factor(1) receptor antagonist. II. Characterization in rodent models of stress-related disorders. J Pharmacol Exp Ther 301:333-345

Groenink L, Pattij T, De Jongh R, Van der Gugten J, Oosting RS, Dirks A, Olivier B (2003) 5-HT1A receptor knockout mice and mice overexpressing corticotropin-releasing hormone in models of anxiety. Eur J Pharmacol 463:185-197

Groenink L, Dirks A, Verdouw PM, de Graaff M, Peeters BW, Millan MJ, Olivier B (2008) CRF1 not glucocorticoid receptors mediate prepulse inhibition deficits in mice overexpressing CRF. Biol Psychiatry 63:360-368

Groenink L, Vinkers C, Oorschot Rv, Olivier B (2009) Models of anxiety: stress-induced hyperthermia (SIH) in singly housed mice. Current Protocols in Pharmacology S45:5.16.1-5.16.12

Hauger RL, Risbrough V, Brauns O, Dautzenberg FM (2006) Corticotropin releasing factor (CRF) receptor signaling in the central nervous system: new molecular targets. CNS Neurol Disord Drug Targets 5:453-479

Hauger RL, Risbrough V, Oakley RH, Olivares-Reyes JA, Dautzenberg FM (2009) Role of CRF receptor signaling in stress vulnerability, anxiety, and depression. Ann N Y Acad Sci 1179:120-143

Heinrichs SC, Koob GF (2004) Corticotropin-releasing factor in brain: a role in activation, arousal, and affect regulation. $\mathrm{J}$ Pharmacol Exp Ther 311:427-440

Heinrichs SC, Lapsansky J, Lovenberg TW, De Souza EB, Chalmers DT (1997) Corticotropin-releasing factor CRF1, but not CRF2, receptors mediate anxiogenic-like behavior. Regul Pept 71:15-21

Heinrichs SC, Li DL, Iyengar S (2001) Corticotropin-releasing factor (CRF) or CRF binding-protein ligand inhibitor administration suppresses food intake in mice and elevates body temperature in rats. Brain Res 900:177-185

Humphries AC, Gancia E, Gilligan MT, Goodacre S, Hallett D, Merchant KJ, Thomas SR (2006) 8-Fluoroimidazo[1,2-a]pyridine: synthesis, physicochemical properties and evaluation as a bioisosteric replacement for imidazo[1,2-a]pyrimidine in an 
allosteric modulator ligand of the GABA A receptor. Bioorg Med Chem Lett 16:1518-1522

Kash TL, Winder DG (2006) Neuropeptide Y and corticotropinreleasing factor bi-directionally modulate inhibitory synaptic transmission in the bed nucleus of the stria terminalis. Neuropharmacology 51:1013-1022

Kehne JH, Cain CK (2010) Therapeutic utility of non-peptidic CRF1 receptor antagonists in anxiety, depression, and stress-related disorders: evidence from animal models. Pharmacol Ther 128:460-487

Kirby LG, Freeman-Daniels E, Lemos JC, Nunan JD, Lamy C, Akanwa A, Beck SG (2008) Corticotropin-releasing factor increases GABA synaptic activity and induces inward current in 5-hydroxytryptamine dorsal raphe neurons. J Neurosci 28:12927-12937

Korosi A, Veening JG, Kozicz T, Henckens M, Dederen J, Groenink L, van der Gugten J, Olivier B, Roubos EW (2006) Distribution and expression of CRF receptor 1 and 2 mRNAs in the CRF overexpressing mouse brain. Brain Res 1072:46-54

Licht CM, de Geus EJ, van Dyck R, Penninx BW (2009) Association between anxiety disorders and heart rate variability in The Netherlands Study of Depression and Anxiety (NESDA). Psychosom Med 71:508-518

Linthorst AC (2005) Interactions between corticotropin-releasing hormone and serotonin: implications for the aetiology and treatment of anxiety disorders. Handb Exp Pharmacol 169:181204

Liu J, Yu B, Neugebauer V, Grigoriadis DE, Rivier J, Vale WW, Shinnick-Gallagher P, Gallagher JP (2004) Corticotropinreleasing factor and Urocortin I modulate excitatory glutamatergic synaptic transmission. J Neurosci 24:4020-4029

Logrip ML, Koob GF, Zorrilla EP (2011) Role of corticotropinreleasing factor in drug addiction: potential for pharmacological intervention. CNS Drugs 25:271-287

Lukkes JL, Forster GL, Renner KJ, Summers CH (2008) Corticotropin-releasing factor 1 and 2 receptors in the dorsal raphe differentially affect serotonin release in the nucleus accumbens. Eur J Pharmacol 578:185-193

McKernan RM, Whiting PJ (1996) Which GABA $A_{\text {-receptor subtypes }}$ really occur in the brain? Trends Neurosci 19:139-143

Millan MJ (2003) The neurobiology and control of anxious states. Prog Neurobiol 70:83-244

Millan MJ, Brocco M, Gobert A, Dorey G, Casara P, Dekeyne A (2001) Anxiolytic properties of the selective, non-peptidergic CRF(1) antagonists, CP154,526 and DMP695: a comparison to other classes of anxiolytic agent. Neuropsychopharmacology 25:585-600

Mirza NR, Larsen JS, Mathiasen C, Jacobsen TA, Munro G, Erichsen HK, Nielsen AN, Troelsen KB, Nielsen EO, Ahring PK (2008) NS11394 [3'-[5-(1-hydroxy-1-methyl-ethyl)-benzoimidazol-1-yl]biphenyl-2-carbonitr ile], a unique subtype-selective $\mathrm{GABA}_{\mathrm{A}}$ receptor positive allosteric modulator: in vitro actions, pharmacokinetic properties and in vivo anxiolytic efficacy. J Pharmacol Exp Ther 327:954-968

Miyata M, Okada D, Hashimoto K, Kano M, Ito M (1999) Corticotropin-releasing factor plays a permissive role in cerebellar long-term depression. Neuron 22:763-775

Mohler H, Fritschy JM, Rudolph U (2002) A new benzodiazepine pharmacology. J Pharmacol Exp Ther 300:2-8

Nicoletti F, Bockaert J, Collingridge GL, Conn PJ, Ferraguti F, Schoepp DD, Wroblewski JT, Pin JP (2010) Metabotropic glutamate receptors: from the workbench to the bedside. Neuropharmacology (in press)

Nie Z, Schweitzer P, Roberts AJ, Madamba SG, Moore SD, Siggins GR (2004) Ethanol augments GABAergic transmission in the central amygdala via CRF1 receptors. Science 303:1512-1514
Niswender CM, Conn PJ (2010) Metabotropic glutamate receptors: physiology, pharmacology, and disease. Annu Rev Pharmacol Toxicol 50:295-322

Nordquist RE, Durkin S, Jaeschke G, Spooren W (2007) Stressinduced hyperthermia: effects of acute and repeated dosing of MPEP. Eur J Pharmacol 568:199-202

Penatti CA, Costine BA, Porter DM, Henderson LP (2009) Effects of chronic exposure to an anabolic androgenic steroid cocktail on alpha5-receptor-mediated GABAergic transmission and neural signaling in the forebrain of female mice. Neuroscience 161:526-537

Petroski RE, Pomeroy JE, Das R, Bowman H, Yang W, Chen AP, Foster AC (2006) Indiplon is a high-affinity positive allosteric modulator with selectivity for alphal subunit-containing $\mathrm{GABA}_{\mathrm{A}}$ receptors. J Pharmacol Exp Ther 317:369-377

Price ML, Curtis AL, Kirby LG, Valentino RJ, Lucki I (1998) Effects of corticotropin-releasing factor on brain serotonergic activity. Neuropsychopharmacology 18:492-502

Rainnie DG, Bergeron R, Sajdyk TJ, Patil M, Gehlert DR, Shekhar A (2004) Corticotrophin releasing factor-induced synaptic plasticity in the amygdala translates stress into emotional disorders. J Neurosci 24:3471-3479

Reul JM, Holsboer F (2002) Corticotropin-releasing factor receptors 1 and 2 in anxiety and depression. Curr Opin Pharmacol 2:23-33

Rudolph U, Mohler H (2006) GABA-based therapeutic approaches: $\mathrm{GABA}_{\mathrm{A}}$ receptor subtype functions. Curr Opin Pharmacol 6:18-23

Savic MM, Majumder S, Huang S, Edwankar RV, Furtmuller R, Joksimovic S, Clayton T Sr, Ramerstorfer J, Milinkovic MM, Roth BL, Sieghart W, Cook JM (2010) Novel positive allosteric modulators of $\mathrm{GABA}_{\mathrm{A}}$ receptors: do subtle differences in activity at alpha1 plus alpha5 versus alpha2 plus alpha3 subunits account for dissimilarities in behavioral effects in rats? Prog Neuropsychopharmacol Biol Psychiatry 34:376-386

Sirinathsinghji DJ, Heavens RP (1989) Stimulation of GABA release from the rat neostriatum and globus pallidus in vivo by corticotropin-releasing factor. Neurosci Lett 100:203-209

Spooren WP, Vassout A, Neijt HC, Kuhn R, Gasparini F, Roux S, Porsolt RD, Gentsch C (2000) Anxiolytic-like effects of the prototypical metabotropic glutamate receptor 5 antagonist 2methyl-6-(phenylethynyl)pyridine in rodents. J Pharmacol Exp Ther 295:1267-1275

Spooren WP, Schoeffter P, Gasparini F, Kuhn R, Gentsch C (2002) Pharmacological and endocrinological characterisation of stressinduced hyperthermia in singly housed mice using classical and candidate anxiolytics (LY314582, MPEP and NKP608). Eur J Pharmacol 435:161-170

Tan H, Zhong P, Yan Z (2004) Corticotropin-releasing factor and acute stress prolongs serotonergic regulation of GABA transmission in prefrontal cortical pyramidal neurons. J Neurosci 24:5000-5008

Ulrich-Lai YM, Herman JP (2009) Neural regulation of endocrine and autonomic stress responses. Nat Rev Neurosci 10:397-409

Ungless MA, Singh V, Crowder TL, Yaka R, Ron D, Bonci A (2003) Corticotropin-releasing factor requires $\mathrm{CRF}$ binding protein to potentiate NMDA receptors via CRF receptor 2 in dopamine neurons. Neuron 39:401-407

Vale W, Spiess J, Rivier C, Rivier J (1981) Characterization of a 41residue ovine hypothalamic peptide that stimulates secretion of corticotropin and beta-endorphin. Science 213:1394-1397

Verkuyl JM, Hemby SE, Joels M (2004) Chronic stress attenuates GABAergic inhibition and alters gene expression of parvocellular neurons in rat hypothalamus. Eur J Neurosci 20:1665-1673

Vinkers $\mathrm{CH}$, van Bogaert MJ, Klanker M, Korte SM, Oosting R, Hanania T, Hopkins SC, Olivier B, Groenink L (2008) Translational aspects of pharmacological research into anxiety 
disorders: the stress-induced hyperthermia (SIH) paradigm. Eur J Pharmacol 585:407-425

Vinkers CH, Groenink L, van Bogaert MJ, Westphal KG, Kalkman CJ, van Oorschot R, Oosting RS, Olivier B, Korte SM (2009a) Stress-induced hyperthermia and infection-induced fever: two of a kind? Physiol Behav 98:37-43

Vinkers CH, Klanker M, Groenink L, Korte SM, Cook JM, Van Linn ML, Hopkins SC, Olivier B (2009b) Dissociating anxiolytic and sedative effects of GABAAergic drugs using temperature and locomotor responses to acute stress. Psychopharmacology (Berl) 204:299-311

Vinkers CH, Bijlsma EY, Houtepen LC, Westphal KG, Veening JG, Groenink L, Olivier B (2010a) Medial amygdala lesions differen- tially influence stress responsivity and sensorimotor gating in rats. Physiol Behav 99:395-401

Vinkers CH, Cryan JF, Olivier B, Groenink L (2010b) Elucidating GABA and $\mathrm{GABA}_{\mathrm{B}}$ receptor functions in anxiety using the stress-induced hyperthermia paradigm: a review. Open Pharmacol J 4:1-14

Yasuhara A, Chaki S (2011) Metabotropic glutamate receptors: potential drug targets for psychiatric disorders. Open Med Chem J 4:20-36

Yu B, Shinnick-Gallagher P (1998) Corticotropin-releasing factor increases dihydropyridine- and neurotoxin-resistant calcium currents in neurons of the central amygdala. J Pharmacol Exp Ther 284:170-179

Zorrilla EP, Koob GF (2010) Progress in corticotropin-releasing factor1 antagonist development. Drug Discov Today 15:371-383 